\title{
STUDY FENOMENOLOGIS PEMILIHAN ALAT KONTRASEPSI PADA WANITA USIA SUBUR PENDERITA HIV/AIDS
}

\author{
Susanti ${ }^{1}$, Widyoningsih ${ }^{2}$ \\ ${ }^{1}$ Program Studi D3 Kebidanan, STIKES Al-Irsyad Al-Islamiyyah Cilacap, Jawa Tengah \\ 2Program Studi Profesi Ners, STIKES Al-Irsyad Al-Islamiyyah Cilacap, Jawa Tengah \\ Email : santirnj@gmail.com
}

\begin{abstract}
ABSTRAK
Latar Belakang: Di seluruh dunia hidup dengan HIV 36, 7 juta orang , 2,1 juta orang yang baru terinfeksi setiap tahunnya, 1,1 juta orang meninggal karena penyakit terkait AIDS. Prevalensi pada wanita muda tetap berisiko terinfeksi HIV yang sangat tinggi. Transmisi HIV masih tetap berlangsung hingga kini, 16.000 jiwa terinfeksi baru setiap harinya. Jumlah ibu hamil dengan HIV pada tahun 2012 berjumlah 3 dan meningkat signifikan pada tahun 2017 menjadi 18 orang.Tingkat pengetahuan yang rendah tentang pentingnya kontrasepsi bagi perempuan HIV mengakibatkan mereka tidak menggunakan kontrasepsi. Pada pasangan yang salah satunya terdiagnosa HIV umumnya pasangan ditegaskan untuk tidak melakukan hubungan seks tanpa kondom.
\end{abstract}

Tujuan: Tujuan menganalisis pilihan kontrasepsi yang digunakan oleh WUS dengan HIV/AIDS Metode: Penelitian ini merupakan penelitian kualitatif yaitu penelitian yang bersifat deskriptif dan menggunakan analisis dengan pendekatan fenomenologis, Populasi dalam penelitian ini adalah Wanita Usia Subur (WUS) penderita HIV/AIDS. Tehnik pengambilan Sampel dengan menggunakan purposive sampling dan didapatkan empat partisipan.

Hasil: Hasil penelitian Berdasarakan wawancara ke empat responden telah menggunakan kontrasepsi "double protection" sebagai upaya untuk menurunkan kejadian penularan dari ibu ke janin dan dari ibu ke pasangan (suami) dengan menggunakan alat kontrasepsi ganda yaitu suntik 3 bulan, IUD, MOW dan Kondom.

Kesimpulan: Wanita Usia Subur penderita HIV/AIDS menggunakan kontrasepsi "double protection".

Kata Kunci: WUS, Jenis Kontrasepsi, HIVIAIDS

\section{PENDAHULUAN}

Penyakit infeksi HIV/AIDS masih merupakan masalah kesehatan global, termasuk di Indonesia. Masalah yang berkembang sehubungan dengan penyakit infeksi HIV/AIDS adalah angka kejadian dan kematian tinggi.World health organization (Lawrance, 2017) melaporkan 36,7 juta orang di seluruh dunia hidup dengan HIV, 2,1 juta orang yang baru terinfeksi setiap tahunnya , 1,1 juta orang meninggal karena penyakit terkait AIDS.

Prevalensi pada wanita muda tetap berisiko terinfeksi HIV yang sangat tinggi. Di Afrika timur dan selatan, misalnya, perempuan muda (usia 15-24 tahun) menyumbang $26 \%$ infeksi HIV baru pada tahun 2016 meskipun hanya 10\% dari populasi. Wanita muda (usia 15-24 tahun) di Afrika bagian barat dan tengah dan Karibia masing-masing menyumbang $22 \%$ dan $17 \%$ infeksi HIV baru pada tahun 2016.(UNAIDS, 2017).

Di seluruh dunia pada tahun 2013 ada 35 juta orang hidup dengan HIV yang meliputi 16 juta perempuan dan 3,2 juta anak berusia $<15$ tahun. Jumlah infeksi baru HIV pada tahun 2013 sebesar 2,1 juta yang terdiri dari 1,9 juta dewasa dan 240.000 anak berusia $<15$ tahun. Jumlah kematian akibat AIDS 
sebanyak 1,5 juta yang terdiri dari 1,3 juta dewasa dan 190.000 anak berusia $<15$ tahun. Hingga saat ini HIV AIDS sudah menyebar di 386 kabupaten/kota di seluruh provinsi di Indonesia. Jumlah kumulatif penderita HIV dari tahun 1987 sampai September 2014 sebanyak 150.296 orang, sedangkan total kumulatif kasus AIDS sebanyak 55.799 orang. (RI, 2014).

Transmisi HIV masih tetap berlangsung hingga kini, 16.000 jiwa terinfeksi baru setiap harinya (Nasrorudin, 2012). Jumlah pasien rawat jalan yang berada di Klinik VCT RSUD Cilacap semakin tahun semakin meningkat. Pasien HIV pada tahun 2013 berjumlah 86 jiwa tahun 2016 berjumlah 90 jiwa dan dan pada tahun 2017 berjumlah 58 jiwa. Jumlah ibu hamil dengan HIV pada tahun 2012 berjumlah 3 dan meningkat signifikan pada tahun 2017 menjadi 18 orang.

Hasil penelitian (Susanti, 2017) karakteristik penderita HIV/AIDS terbanyak pada umur 25-49 tahun sebesar $74 \%$, jenis kelamin laki - laki sebesar $58.6 \%$, status perkawinan didapatkan data terbanyak sudah menikah sebesar $67.1 \%$, transmisi penularannya terbanyak adalah melalui lain lain sebesar $40.1 \%$, ibu hamil penderita HIV/AIDS terbanyak pada tahun 2016 tebanyak $40.47 \%$. Transmisi HIV masuk dalam tubuh manusia melalui tiga cara, yaitu : dari ibu terinfeksi HIV ke bayi, melalui hubungan seksual, dan kontak antar darah yang terinfeksi (Nasrorudin, 2012).

Penyebab terjadunya unwanted pregnancy karena hubungan seks dini, berganti-ganti pasangan seks dan pasangan yang tidak tahu tentang status kesehatan pasangan seksualnya yang terkena HIV/AIDS
(Kancheva, Lakhonphon, \& Ananworanich, 2011). Jumlah kehamilan yang tidak diinginkan pada perempuan penderita HIV mencapai $15-58 \%$ di Rwanda.Tingkat pengetahuan yang rendah tentang pentingnya kontrasepsi bagi perempuan HIV mengakibatkan mereka tidak menggunakan kontrasepsi (Adebola, Abboud, Merdekios, \& Sfhiferaw, 2012). Kehamilan pada penderita HIV dapat mengakibatkan penurunan jumlah CD4. Penurunan tersebut umumnya kurang lebih 50.

Pemilihan kontrasepsi pada perempuan dengan infeksi HIV/AIDS perlu diidentifikasi dan diberikan penjelasan pemilihan kontrasepsi yang sedikit berbeda dengan perempuan yang tidak menderita HIV (Adebola et al., 2012). Perempuan penderita HIV positif selain menggunakan kontrasepsi untuk mencegah terjadinya unwanted pregnancy, mereka juga perlu menggunakan double protection agar tidak menularkan kepada pasangannya (NCCID, 2010).

Penggunaan kondom pria secara konsisten telah terbukti mengurangi penularan HIV secara horisontal hingga $80 \%$ di antara pasangan serodiskordan HIV. Kontrasepsi hormonal dapat meningkatkan risiko penularan HIV pada wanita berisiko tinggi seperti pekerja seks komersial, namun tidak pada wanita dengan risiko HIV rendah. Kontrasepsi hormonal tidak mengganggu efektivitas obat antiviral (Heikinheimo \& Hteenma"ki, 2009) (B et al., 2015).

Infeksi HIV/AIDS sampai saat ini belum ditemukan obat dan vaksin (RI, 2014) jika perempuan yang masih dalam usia produktif manderita HIV/AIDS hal ini akan mengakibatkan resiko penularan vertical 
kepada bayi disetia kehamilannya. Penularan dari ibu ke janin saat ini menjadi penyebab kedua terbesar di dunia terjadinya penularan penyakit HIV (Wolfgang, Stover, Esiru, Harper, \& Tappero, 2009).

Kontrasepsi merupakan komponen utama PMTCT yang berguna untuk perempuan dan laki-laki yang menderita HIV positif selain untuk pencegahan primer dan terjadinya inveksi HIV berulang, kontrasepsi juga dapat mengurangi kejadian kehamilan yang tidak direncanakan agar tidak meningkatkan resiko penularan kepada bayi yang dikandung (AK \& KS, 2012). Pemilihan kontrasepsi pada perempuan dengan penyakit infeksi HIV/AIDS memerlukan konseling untuk meningkatkan kesehatan reproduksinya secara komprehensif dan yang paling penting kontrasepsi pada pengguna HIV adalah untuk mencegah penularan virus HIV dari ibu ke janin serta penularan kepada pasangan seksualnya.

Data akseptor keluarga berencana (KB) pasien HIV di Klinik VCT RSUD Cilacap belum dicatat sehingga penulis tertarik untuk meneliti Analisis Pilihan Kontrasepsi pada Wanita Usia Subur dengan HIV/AIDS di RSUD Cilacap. Tujuan penelitian ini untuk menganalisis pilihan kontrasepsi yang digunakan oleh WUS dengan HIV/AIDS.

\section{METODE}

Penelitian ini merupakan penelitian kualitatif yaitu penelitian yang bersifat deskriptif dan cenderung menggunakan analisis dengan pendekatan induktif. Desain yang digunakan adalah fenomenologis, Populasi dalam penelitian ini adalah Wanita Usia Subur (WUS) penderita HIV/AIDS.
Tehnik pengambilan Sampel dengan menggunakan purposive sampling dan didapatkan sebanyak empat partisipan.

Metode pengumpulan data yang digunakan dalam penelitian ini adalah menggunakan tehnik wawancara mendalam (indepth interview) sesuai dengan pedoman wawancara yang telah disusun peneliti (W, 2010). Dalam penelitian ini setelah semua data terkumpul lalu dibuat transkrip selanjutnya dilakukan analisa, pengkategorian- pengkategorian yang selanjutnya akan menghasilkan tema- tema dan dibuat kesimpulan

\section{HASIL}

\section{Gambaran Karateristik Informan}

Informan yang berpartisipasi pada penelitian ini wanita usia subur sebanyak 4 orang. Usia informan berkisar antara 27 tahun sampai dengan 39 tahun. Pekerjaan informan semuanya ibu rumah tangga. Keyakinan semua informan beragama Islam dan merupakan suku jawa. Lamanya menderita HIV /AIDS antara 5 tahun sampai dengan 7 tahun.

Tabel 1. Karakteristik Informan

\begin{tabular}{ccc}
\hline $\begin{array}{c}\text { Jenis } \\
\text { Kontrasepsi }\end{array}$ & Usia & $\begin{array}{c}\text { Lama } \\
\text { HIV/AIDS }\end{array}$ \\
\hline MOW+Kondom & 34 tahun & 5 tahun \\
Suntik+Kondom & 30 tahun & 7 tahun \\
MOW+Kondom & 27 tahun & 6 tahun \\
IUD+Kondom & 39 tahun & 5 tahun \\
\hline
\end{tabular}

Berdasarkan tabel dari empat informan usia tiga orang pada usia 20-35 tahun, dan usia $>35$ tahun satu orang. Semuanya telah menggunakan double protection, dan lama terdiagnosa HIV/AIDS semuanya lebih dari lima tahun. 
Susanti, Widyoningsih| Study Fenomenologis Pemilihan Alat Kontrasepsi pada Wanita Usia Subur Penderita HIV/AIDS

\section{Analisis Tematik}

Pada Gambar 1, terlihat terlihat bahwa skema pilihan alat kontrasepsi pada Wanita Usia Subur (WUS) dengan HIV/AIDS semuanya menggunakan double protection antara lain suntik 3 bulanan dan kondom, IUD dan kondom, MOW dan kondom

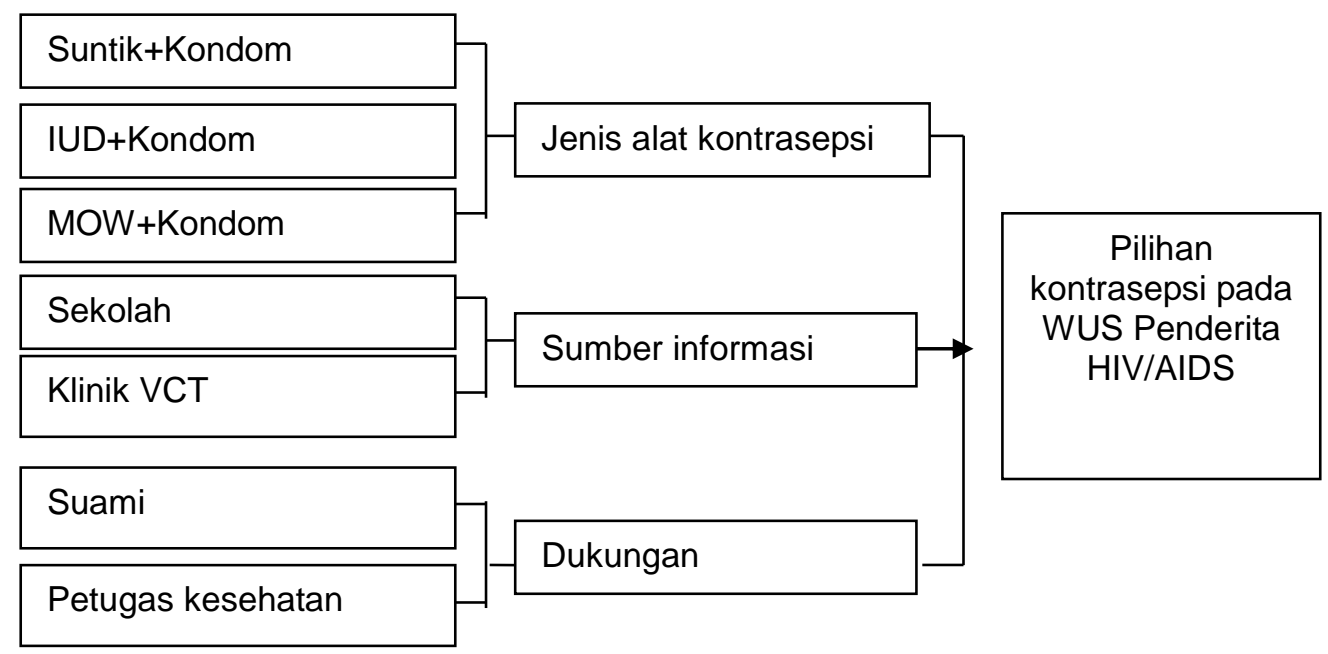

Gambar 1. Skema Pemilihan Kontrasepsi

Pilihan dan faktor yang berperan dan pemilihan kontrasepsi :

\section{a. Pilihan jenis kontrasepsi}

Seluruh informan menggunakan alat kontrasepsi dan menggunakan double protection setelah konsultasi oleh tim kesehatan di Klinik VCT Cahaya Pita RSUD Kabupaten Cilacap. Kondisi ini memungkinkan informan mendapatkan informasi yang cukup tentang pencegahan penularan baik penularan ke janin dan pasangan (suami). Hal tersebut dapat membantu informan lebih cepat memahami dan benar dalam pilihan alat kontrasepsi yang digunakan.

Penelitian ini menemukan sebagian besar informan menyatakan bahwa dengan menggunakan alat kontrasepsi ganda merupakan salah satu cara untuk mencegah penularan terjadinya kehamilan dan mencegah penularan terhadap pasangan (suami). Respon informan digambarkan sangat bervariasi seperti yang dmiungkapkan oleh beberapa informan berikut ini :

“....lya,Menurut saya KB yang saya pakai sudah tepat untuk mencegah kehamilan dan penularan dengan pakai KB suntik 3 bulanan dan selalu pakai kondom saat hubungan seksual sama suami" (I.2)

“... Saya pakai steril bu sama kondom” (I.3)

"...sekarang saya pakai KB IUD sama kondom bu" (I.4)

\section{b. Sumber Informasi tentang pencegahan penularan}

Respon yang diberikan informan juga menunjukkan bahwa informan dapat informasi tentang pencegahan penularan salah satunya adalah dnegan pakai alat kontrasepsi dapat menurunakn penularan terhadap janin dan pakai kondom dapat menurunkan penularan terhadap pasangan (suami) . Respon yang ditunjukan juga sangat bervariasi seperti yang yang diungkapkan oleh beberapa informan berikut : 
"....Saat sebelum menikah saya sudah tau bagaimaa cara mencegah tertular HIVIAIDS tapi saya tertular suami saya yang pertama dan saya tidak tau kalu suami saya mengidap HIV/AIDS positif,...." (I.1)

"...Saya tau cara pencegahan ya saat pertama kali ke Rumah Sakit dikasih tau sama petugas di klinik VCT.... "(I.2)

“...saya periksa ke RSUD ya saya taunya pertama kali ya dari petugas klinik VCT RSUD Cilacap... (I.3)

\section{c. Dukungan}

Respon yang diberikan informan juga menunjukkan bahwa informan dapat dukungan dari pasangan (suami) . Respon yang ditunjukan juga sangat bervariasi seperti yang yang diungkapkan oleh beberapa informan berikut :

“....Yang paling mendukung adalah adanya dukungan dan persetujuan dari suami bu sama petugas petugas klinik VCT,...." (I.1)

“....yang penting suami saya mendukung bu sama KB yang akan saya pakai dan ya petugas di klinik VCT.... "(I.2)

"....yang membantu saya ya suami sama petugas-petugas klinik VCT... (I.3)

\section{PEMBAHASAN}

Seluruh informan sudah menggunakan alat kontrasepsi dan dari ke empat informan yang menggunakan kontrasepsi hormonal suntik Depo Medroksi Progesteron Acetat (DMPA) sebanyak 2 orang, menggunakan Intra Uterine Device (IUD) dan Metode Operasi Wanita (MOW) masing-masing 1 orang.

Hasil penelitian yang dilakukan oleh (M. M. A, 2016) bahwa hubungan antara status HIV dan pilihan metode kontrasepsi konsisten dengan pola yang diharapkan, dengan perempuan yang positif HIV lebih dari dua kali lebih mungkin untuk menggunakan kondom daripada kontrasepsi hormonal, dibandingkan dengan rekan-rekan mereka yang memiliki karakteristik serupa yang HIV-negatif. <0,05. Hasil penelitian menunjukkan bahwa status HIV adalah penentu yang signifikan dari pilihan metode, dengan perempuan HIV-positif lebih cenderung menggunakan kondom atau pantang berkala daripada kontrasepsi hormonal (pil atau suntikan). Perempuan yang positif HIV lebih dari dua kali menggunakan kondom daripada kontrasepsi hormonal dibandingkan dengan rekan-rekan mereka yang memiliki karakteristik serupa yang HIV-negatif $(R R=2,41)$.

Di Uganda mayoritas klien menggunakan kondom 58\%, diikuti oleh suntikan pada 29\%. Dalam penelitian lain, suntikan adalah jenis metode kontrasepsi yang paling sering digunakan yang menyertainya $70,7 \%$ pengguna (Sarah et al., 2012). Lebih banyak lagi Wanita yang hidup dengan HIV tampaknya memiliki tingkat kehamilan yang tidak diinginkan lebih tinggi (51-90\%), dibandingkan dengan perkiraan global yang lebih luas (38\%) (Homsy et al., 2009). Selain itu, kemungkinan kehamilan untuk perempuan yang terinfeksi HIV hingga tiga kali lebih tinggi setelah memulai terapi antiretroviral (ART) . (Landon et al., 2010).

Penelitian oleh (Phillips, Polis, \& Curtis, 2016) bahwa tidak ada peningkatan risiko untuk pengembangan penyakit HIV atau kematian terkait dengan penggunaan kontrasepsi oral dengan rasio $(\mathrm{HR}) \quad 0,83$, interval kepercayaan [CI] 0,48-1,44] atau suntikan (adj HR 0,72, Cl 0,53-0,98). Tiga 
penelitian baru tidak menemukan peningkatan risiko yang signifikan untuk ukuran penularan HIV dari perempuan ke laki-laki dengan penggunaan kontrasepsi hormonal.

Sedangkan pil kontrasepsi oral kombinasi mengidentifikasi penurunan serum estrogen dan tingkat progestin ketika dipakai bersamaan dengan ARV tertentu. Efek kontrasepsi dari depot medroksiprogesteron asetat suntik (DMPA) dan sistem intrauterin levonorgestrel (LNG-IUS) sebagian besar tidak dipengaruhi oleh ARV, sementara data pada patch, cincin, dan implan kontrasepsi kurang (R. J. A, Jamshidi, \& Burke, 2012).

Sedangkan pada penelitian yang dilakukan oleh (M \& Schreiber, 2011) bahwa penggunaan kontrasepsi intrauterin levonorgestrel-releasing adalah WHO Kategori 3 (risiko lebih besar daripada manfaat) untuk pasien HIV-positif dan pelunya untuk promosi terkait tentang infeksi menular seksual (IMS) / penyakit radang panggul (PID) dan peningkatan risiko penularan.

Berdasarkan hasil wawancara ke empat responden sudah menggunakan alat kontrasepsi ganda dengan menggunakan metode kontrasepsi jangka panjang (suntik 3 bulan, IUD dan MOW) dan juga menggunakan kondom sebagai pencegahan supaya tidak menularkan terhadap pasangan. Hal ini telah sesuai dengan beberapa penelitian yang telah dilakukan sebelumnya.

Pemilihan jenis alat kontrasepsi berdasarkan hasil wawancara sangat didukung oleh pasangan (suami) dan tenaga kesehatan, hal ini dipekuat oleh penelitian yang dilakukan oleh Imbuki Kennedy, et al (2010) bahwa persepsi tentang efek samping, pendapat pasangan pria, dan pengembangan penyakit HIV memainkan peran penting dalam keputusan jenis kontrasepsi yang akan digunakan. Sealin itu juga yang kemungkinan berpengaruh adalah pengetahuan wanita tentang bagaimana cara pencegahan supaya tidak menularkan ke pasangan (suami) atau ke janinnya dengan tida menyusui bayinya, dari ke empat responden.

\section{KESIMPULAN DAN SARAN}

Wanita Usia Subur penderita HIV/AIDS menggunakan kontrasepsi "double protection". Perlu adanya standar asuhan kebidanan pelayanan Keluarga Berencana pada paisen HIV/AIDS untuk petugas kesehatan

\section{DAFTAR PUSTAKA}

A, M. M. (2016). HIV/AIDS and Contraceptive Method Choice: Demographic and Socio-Economic Correlates of Contraceptive Method Choice Among HIV-Positive Women Practising Family Planning in Kenya. HIVIAIDS Reserach And Treatment Open Journal, 3(1), $1-12$. https://doi.org/10.17140/HARTOJ-3-119

A, R. J., Jamshidi, R., \& Burke, A. E. (2012). Contraception for the HIV-Positive Woman: A Review of Interactions between Hormonal Contraception and Antiretroviral Therapy. Infectious Diseases in Obstetrics and Gynecology. https://doi.org/10.1155/2012/890160

Adebola, A., Abboud, N., Merdekios, B., \& Sfhiferaw, M. (2012). Qualitative Study of Barriers to Effectiveness of Interventions to PreventMother-to-Child Transmission of HIV in ArbaMinch, Ethiopia. International Journal of Population Research.

https://doi.org/10.1155/2012/532154

AK, M., \& KS, H. (2012). Barriers to Contraception HIV-Positive Women in a Periurban District of Uganda. International Journal of STD \& AIDS. https://doi.org/org/10.1258/ijsa.2009.009 
357

B, H. L., Feldacker, C., Jamieson, D. J., Tweya, H., Cwiak, C., Chaweza, T., ... Phiri, S. (2015). . Pregnancy Prevention and Condom Use Practices among HIV-Infected Women on Antiretroviral Therapy Seeking Family Planning in Lilongwe, Malawi. PLOS ONE, 10 (3). https://doi.org/0.1371/journal. pone.0121039

Heikinheimo, O., \& Hteenma"ki, P. L. (2009). Contraception and HIV infection in women. Human Reproduction Update, 15 , 165-176. https://doi.org/Doi:10.1093/humupd/dmn 049

Homsy, J., Bunnell, R., Moore, D., King, R., Malamba, S., Nakityo, R., ... Mermin, J. (2009). Reproductive intentions and outcomes among women on antiretroviral therapy in rural Uganda: A prospective cohort study. PLOS ONE. https://doi.org/org/10.1371/journal.pone. 0004149

Kancheva, L. N. T., Lakhonphon, S., \& Ananworanich, J. (2011). Contraception in HIV- positive Female Adolescent. AIDS Reserach And Therapy. https://doi.org/10.1186/1742-6405-8-19

Landon, M., Carter, R. J., Katyal, M., Toro, P., El-Sadr, W. M., \& Abrams, E. J. (2010). Impact of antiretroviral therapy on incidence of pregnancy among HIV-infected women in Sub-Saharan Africa: A cohort study. Plos Medicine, $7(2)$.

https://doi.org/org/10.1371/journal.pmed .1000229

Lawrance, G. (2017). HIV/AIDS in the world 2017 Epidemiology and Issues. Retrieved from https://medicine.usask.ca/documents/al umni/Highlights-2017-HIV-Gelmon.pdf

M, Q. S., \& Schreiber, C. A. (2011). IUD use in HIV-positive women. An International Reproductive Health Journal Contraception, 83(2), 99-101. https://doi.org/org/10.1016/j.contraceptio n.2010.05.011

Nasrorudin. (2012). , Pendekatan Biologis Molekuler, Klinis dan Sosial HIV \& AIDS. Surabaya: Airlangga University Press.

NCCID. (2010). No TitleContraception Methods for HIV-Positive Women and Women at Risk of HIV. Retrieved from https://nccid.ca/publications/contraceptio n-methods-for-hiv-positive-women-andwomen-at-risk-of-hiv/
Phillips, S. J., Polis, C. B., \& Curtis, K. M. (2016). The safety of hormonal contraceptives for women living with HIV and their sexual partners. Contraception, 93, 11-16. https://doi.org/org/10.1016/j.contraceptio n.2015.10.002

RI, K. (2014). Info Datin Pusat Data Dan Informasi Kemenkes RI. Jakarta. Retrieved from \%0Awww.depkes.go.id/resources/.../info datin/Infodatin AIDS.pdf\%OA

Sarah, C., Hoke, T., Constant, D., Green, M. S., Moodley, J., \& Harries, J. (2012). Factors impacting knowledge and use of long acting and permanent contraceptive methods by postpartum HIV positive and negative women in Cape Town, South Africa: A cross sectional study. BMC Public Health, 12, 197.

Susanti. (2017). Karakteristik Penderita HIV-AIDS Di Klinik VCT Rumah Sakit Umum Daerah Cilacap Tahun 2013-2016. Viva Medika, 10, 20-27.

UNAIDS. (2017). UNAIDS Data 2017. Retrieved from http://www.unaids.org/sites/default/files/ media_asset/20170720_Data_book_20 $1 \% 0 \mathrm{~A} \% 0 \mathrm{~A}$

W, C. J. (2010). Research Design Pendekatan Kualitatif, Kuantitatif dan Mixed. Yogyakarta: Pustaka Pelajar.

Wolfgang, H., Stover, J., Esiru, G., Harper, M., \& Tappero, J. (2009). The Contribution of Family Planning Towards the Prevention of Vertical HIV Transmission in Uganda. PLOS ONE, 4(11), e7691. 